\title{
In vitro analysis of gluten-free foods containing quinoa (Chenopodium quinoa Willd.)
}

\author{
Victor F. Zevallos ${ }^{1}$, L. Irene Herencia ${ }^{2}$, H. Julia Ellis ${ }^{1}$ and Paul J. Ciclitira ${ }^{1}$ \\ ${ }^{1}$ King's College London, London, UK and ${ }^{2}$ Universidad Politécnica de Madrid, Madrid, Spain
}

The only effective treatment for patients suffering from coeliac disease (CD) is to follow a strict gluten-free diet (GFD). Permanent avoidance of gluten from the diet is essential in patients with CD to maintain a normal intestinal mucosa and to reduce the risk of complications. The GFD includes naturally-occurring gluten-free foods such as fruit, vegetables, unprocessed meat, fish and poultry. Gluten-free substitute foods such as pasta, bread, cereals, crackers and snack foods in which wheat flour is replaced by gluten-free flours from rice, millet, maize and recently quinoa can also be ingested. It has been suggested that quinoa cultivars may be a safe alternative for patients with $\mathrm{CD}^{(1)}$. However, the incorporation of quinoa into processed foods may be accompanied by the risk of contamination with gluten mainly as a result of poor manufacturing practices. Thus, the safety of different quinoa products marketed as gluten-free in the UK has been assessed.

Dot immuno-binding assays were performed using four murine monoclonal antibodies $(\mathrm{mAb})$ to known coeliac-toxic gluten proteins and peptides. Furthermore, ELISA was used to determine the presence of toxic peptides. Prolamins were extracted from fifteen quinoa products and three commercially-obtained wheat starches of known gluten content, which were acceptable, borderline and unacceptable for a GFD, using an in-house extraction buffer with a reducing agent. All samples were spotted onto a nitrocellulose membrane and exposed separately to the antibodies, enzyme-linked anti-mouse secondary antibody and chromogen. The ELISA was performed using a monoclonal antibody to a toxic A-gliadin peptide and the plates were read in an ELISA plate reader using a $405 \mathrm{~nm}$ filter.

Strong, moderate and negative reactions were observed in the unacceptable, borderline and acceptable wheat starches when exposed to the four monoclonal mAb. Nine quinoa products exhibited negative results but four products, including quinoa pasta, flakes, flours and commercial grains, gave borderline or positive results with one or both of the anti-gliadin antibodies. Furthermore, when quantitative ELISA $^{(2)}$ was used it was found that three products had no detectable gliadin, as measured by PN3 (anti-A-gliadin 31-49). However, the pasta had a gluten content of 76 parts $/ 10^{6}$, an amount greater than the maximum of 20 parts $/ 10^{6}$ proposed for naturally gluten-free foods ${ }^{(3)}$.

Quinoa may be a safe alternative for patients with CD. However, some quinoa products advertised as gluten-free have high levels of gluten. Since new legislation to regulate the minimum permitted level of gluten contamination of gluten-free foods is expected to come into place in the near future, further tests will be undertaken to assess the safety of new and existing gluten-free products.

This study was supported by the Food Standards Agency (PG1017).

1. Zevallos V, Ciclitira PJ, Suligoj T, Herencia LI \& Ellis HJ (2007) Proc Nutr Soc 66, 69A.

2. Ellis HJ, Rosen-Bronson S, O'Reilly N \& Ciclitira PJ (1998) Gut 43, 190-195.

3. Codex Alimentarius Commission (2003) Draft Revised Standards for Gluten-free Foods. Report of the 25th Session of the Codex Committee on Nutrition and Foods for Special Dietary Uses. Rome: FAO. 